\title{
Larval polytene chromosomes of three Japanese blackfly species (Diptera: Simuliidae)
}

\author{
Upik Kesumawati HAdI, ${ }^{1)}$ Hiroyuki TAKAOKA ${ }^{1)}$ and Chiharu AoKI ${ }^{1)}$ \\ Division of Medical Zoology, Oita Medical University, Hasama, Oita 879-55, Japan
}

(Received: 8 September 1995; Accepted: 1 December 1995)

Key words: blackfly, Simuliidae, Simulium, poly tene chromosome

\begin{abstract}
Standard maps of larval salivary gland polytene chromosomes of three Japanese blackfly species: i.e., Simulium bidentatum (Shiraki, 1935), S. aokii (Takahasi, 1941) and $S$. arakawae Matsumura, 1915, were presented. All the three species had three paired chromosomes $(2 n=6)$ and showed other main characteristics in common, such as a Balbiani ring, a double bubble, a parabalbiani ring and a nucleolar organizer on the same arm of the same chromosome. However, their precise locations were different among the species. All species had prominent centromeres, the banding patterns of which were different among them. In S. bidentatum and $S$. aokii polymorphic inversions were found in low frequencies, and B-chromosomes were also detected. Any sex chromosomes or sex-linked segments could not be detected.
\end{abstract}

\section{INTRODUCTION}

Morphotaxonomic and cytotaxonomic data of blackflies have been accumulated (Rothfels, 1979), but they alone cannot fully describe the true biological nature. Analysis of larval salivary gland polytene chromosomes has often revealed that an isomorphic species is composed of biologically distinct sibling species (e.g., Rothfels, 1956; Dunbar, 1966; and Hirai et al., 1994).

Knowledge of cytotaxonomy of Japanese blackflies is very scarce. Only a few reports have been presented previously (Okada, 1972, 1974; Hirai et al., 1984; Hadi et al., 1995). This paper describes the larval polytene chromosomes of Simulium bidentatum (Shiraki, 1935), S. aokii (Takahasi, 1941), and S. arakawae Matsumura, 1915 , all of which are well-known pest to men and domestic animals in Japan

\footnotetext{
1) Hadi, U. K., 高岡宏行, 青木干春：大分医科大学医動物学教 室（干 879-55 大分県大分郡㣣間町医大ヶ丘 1-1）
}

(Ogata, 1955; Takaoka, 1977), and vectors of bovine onchocerciasis in some localities (Takaoka et al., 1992; Takaoka, 1994).

\section{Materials And Methods}

The larvae of S. bidentatum, S. aokii and S. arakawae were collected from streams and rivers at Hasama, Notsuharu, Taketa, Yabakei, Yufuin (all in Oita Prefecture), and Kikuchi (Kumamoto Prefecture). The number of larvae observed for each species is presented in Table 1. The larvae were removed from the vegetation to which they attached, using forceps and then placed in vials which were filled with freshly-prepared acetic alcohol (glacial acetic acid: ethanol $=1: 2$ ). Fixed larvae were stored in a freezer $\left(-20^{\circ} \mathrm{C}\right)$ until required for slide preparation. Larval identification was carried out according to Takaoka (1977). Chromosome preparation and sexing of larvae were done as described in the previous paper (Hadi et al., 1995). 
Table 1. Samples of larvae of three Japanese blackfly species analyzed cytologically.

\begin{tabular}{|c|c|c|c|c|c|c|c|}
\hline \multirow{3}{*}{ Location } & \multirow{3}{*}{ Date } & \multicolumn{6}{|c|}{ No. larvae examined* } \\
\hline & & \multicolumn{2}{|c|}{ S. bidentatum } & \multicolumn{2}{|c|}{ S. aokii } & \multicolumn{2}{|c|}{ S. arakawae } \\
\hline & & Female & Male & Female & Male & Female & Male \\
\hline Hasama (Oita) & 20 IV 92 & 23 & 27 & 5 & 15 & 49 & 18 \\
\hline Notsuharu (Oita) & 27 IV 92 & 41 & 21 & 0 & 1 & 0 & 0 \\
\hline Yabakei (Oita) & $12 \operatorname{IV} 94$ & 10 & 5 & 6 & 1 & 0 & 0 \\
\hline Yufuin (Oita) & 12 IV 94 & 0 & 0 & 5 & 4 & 0 & 0 \\
\hline Taketa (Oita) & 07 IV 92 & 15 & 18 & 0 & 0 & 0 & 0 \\
\hline Kikuchi (Kumamoto) & $08 \times 92$ & 13 & 14 & 0 & 0 & 10 & 9 \\
\hline Total & & 102 & 85 & 16 & 21 & 59 & 27 \\
\hline
\end{tabular}

* The number of larvae of which chromosome preparation was good enough for analysis.

Mapping of the polytene chromosomes followed the conventional method of Bedo (1977) and Rothfels et al. (1978). Measurements of polytene chromosomes were made from photographs of 10 cells spread. The percentage of each chromosome arm to the total complement length (TCL) was used to determine the approximate number of sections assigned to each arm in the standard map. The polytene chromosomes of the three species examined from the Yufugawa river were used for the standard map.

\section{RESUlts}

General chromosome morphology. All the three species observed in this study had three pairs of chromosomes $(2 n=6)$. The longest pair was chromosome I and the shorter pairs were chromosomes II and III in descending order of length. The long arms of the latter two chromosomes were equal in length but the short arms were different, the arm of chromosome II being slightly longer. The relative lengths of three chromosomes and also of their arms were the same in all the three species, then the same number of sections were assigned (Table 2). The centromeres of these three species each formed a characteristic expanded region. Pairing of the homologues was relatively loose in $S$. arakawae, but very tight in the other two species.

Supernumerary chromosomal fragments
(B-chromosome) were detected in four of five populations of $S$. bidentatum and in one of four populations of $S$. aokii examined (Fig. 9a-d). The frequency of the larvae having B-chromosome(s) in the positive populations was $10-22 \%$ for $S$. bidentatum, and $15 \%$ for S. aokii.

$S$. bidentatum. The standard chromosome maps of $S$. bidentatum are presented in Figs. 1-3. The centromeric regions had an intense dark band in the middle. The short arm of chromosome I (IS) was characterized by a group of two heavy bands in section $4 \mathrm{BC}$, and three heavy bands in 16. The long arm of chromosome I (IL) had a region of fine bands in 20B-21, shield-like pattern in $26 \mathrm{~B}$ and $34 \mathrm{~A}$, and a group of fine light bands in $38 \mathrm{~B}$ (the 'neck'). The tip of this arm was characterized by some fine bands. The IIS bore the ring of Balbiani (RB) in $43 \mathrm{~A}$, the double bubble $(\mathrm{db})$ in 44 , and the basal trapezoidal group (tr) in 53. The long arm was distinguished by the Parabalbiani ring (PB) in $69 \mathrm{C}$. The IIIS had the puffed alveolar region (blister, B) accompanied distally by two distinct light bands in $75 \mathrm{BC}$, and the conspicuous 'capsular' saw-toothed puffing entity $(\mathrm{Ca})$ in $78 \mathrm{C}$. The IIIS was flared at the tip. In the IIIL were located the nucleolar organizer region (NO) (in 90) and three heavy band groups (in 99).

In all the six populations examined, one heterozygous inversion, IIIL-1 (85B-85/86) (Figs. 3 and $9 \mathrm{e}$ ), was commonly found in 
Table 2. Percentage of chromosome arms to the total complement length (\% TCL) from 10 nuclei of larval salivary gland cells of three Japanese blackfly species.

\begin{tabular}{lccc}
\hline \hline & S. bidentatum & S. aokii & S. arakawae \\
\hline IS & $18.7 \pm 1.3(19)^{*}$ & $18.9 \pm 1.6(19)$ & $18.6 \pm 1.6(19)$ \\
IL & $22.0 \pm 1.0(22)$ & $22.1 \pm 1.2(22)$ & $21.9 \pm 1.1(22)$ \\
R** & $1.2(\mathrm{M})$ & $1.2(\mathrm{M})$ & $1.2(\mathrm{M})$ \\
IIS & $12.8 \pm 1.3(13)$ & $12.9 \pm 1.6(13)$ & $12.9 \pm 1.7(13)$ \\
IIL & $18.3 \pm 1.0(18)$ & $17.8 \pm 1.7(18)$ & $18.0 \pm 1.3(18)$ \\
R & $1.4(\mathrm{M})$ & $1.4(\mathrm{M})$ & $1.4(\mathrm{M})$ \\
IIIS & $10.4 \pm 1.1(10)$ & $10.3 \pm 0.6(10)$ & $9.8 \pm 1.2(10)$ \\
IIIL & $17.8 \pm 1.5(18)$ & $18.3 \pm 1.7(18)$ & $18.6 \pm 1.0(18)$ \\
R & $1.7(\mathrm{SM})$ & $1.8(\mathrm{SM})$ & $1.9(\mathrm{SM})$ \\
\hline
\end{tabular}

* Parentheses indicate the number of sections assigned to the arms in the standard chromosome map.

** R: arm ratio (long arm/short arm), M, metacentric; SM, submetacentric (identification followed Levan et al., 1964).

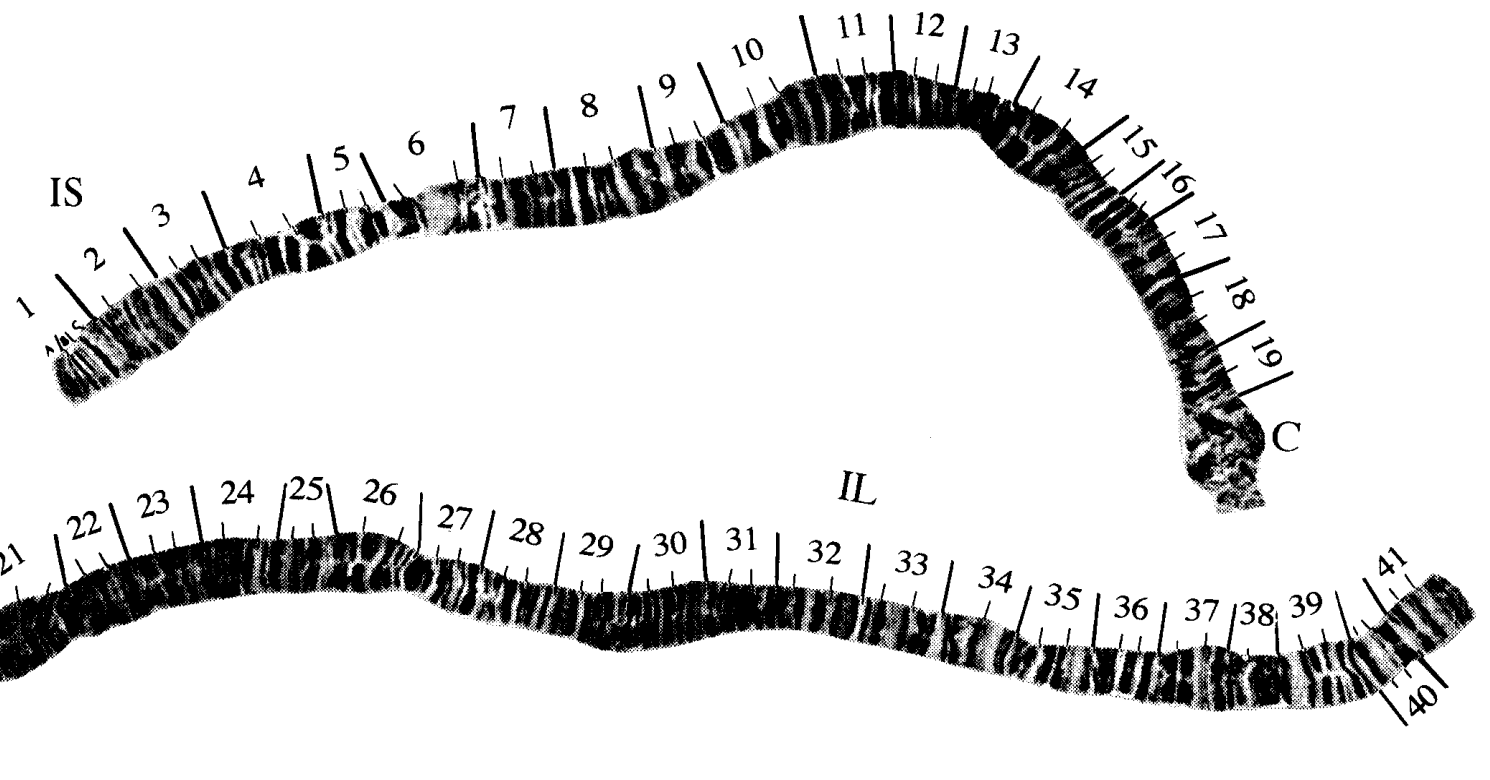

Fig. 1. Larval salivary gland chromosome I of female Simulium bidentatum. IS, short arm; IL, long arm; C, centromere. Numbers 1-41 indicate sections; A, B and C indicate subsections.

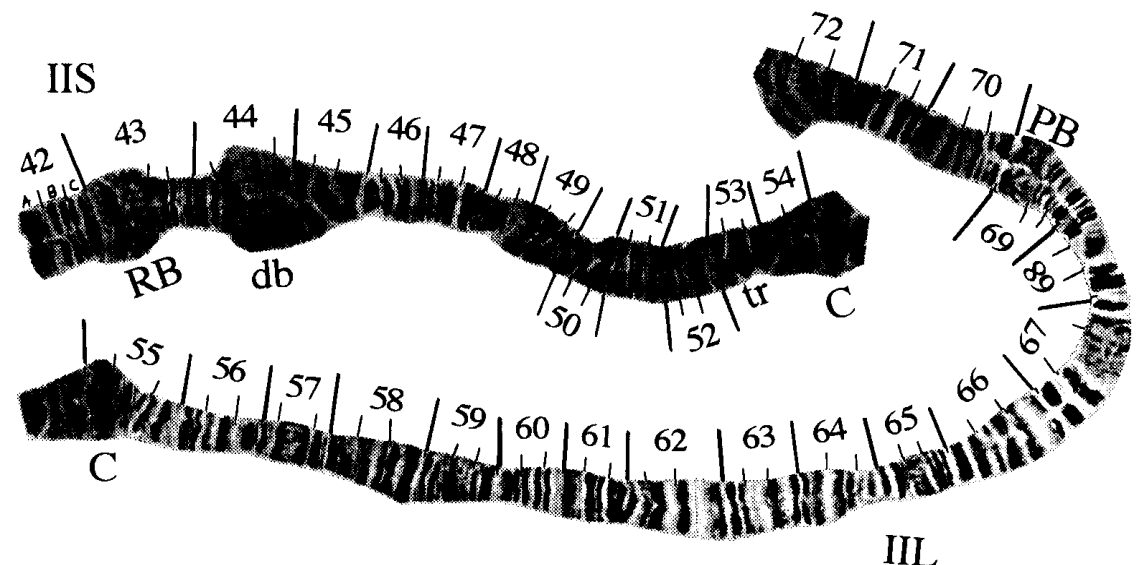

Fig. 2. Larval salivary gland chromosome II of female Simulium bidentatum. IIS, short arm; IIL, long arm; $\mathrm{C}$, centromere; $\mathrm{RB}$, ring of Balbiani; $\mathrm{db}$, double bubble; tr, trapezoidal group; $\mathrm{PB}$, parabalbiani ring. Serial numbers and alphabets are as Fig. 1. 

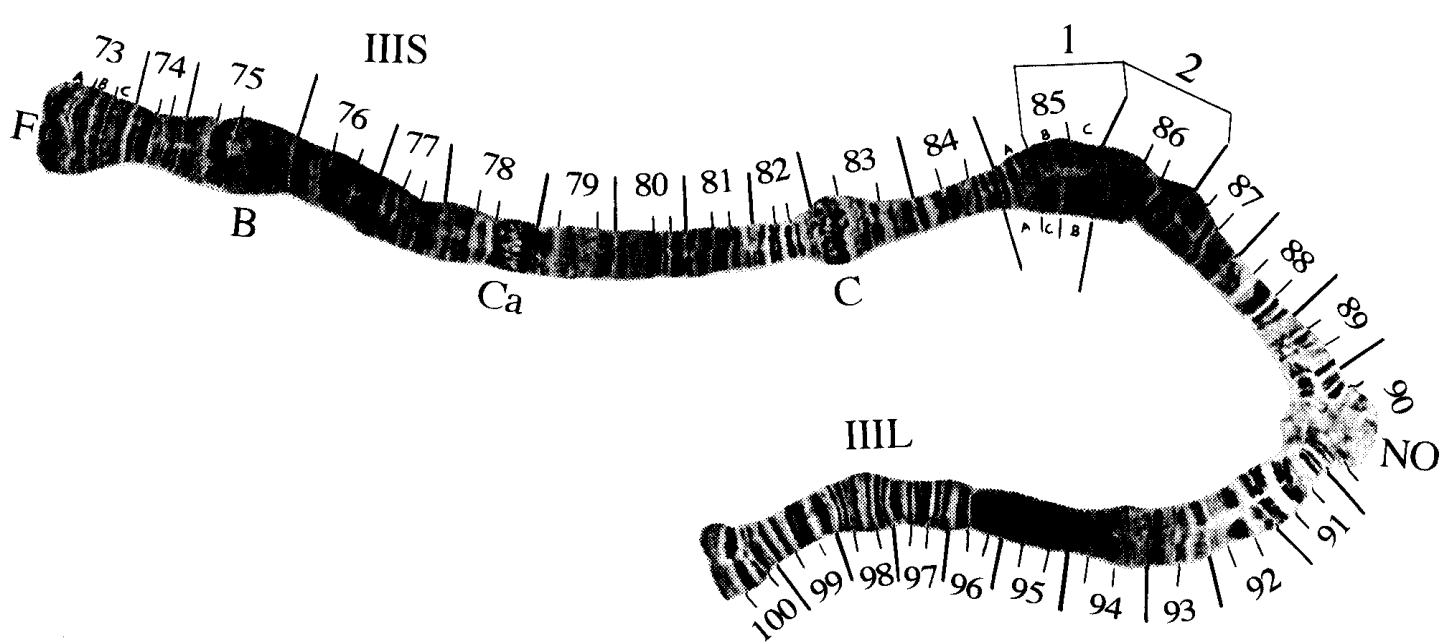

Fig. 3. Larval salivary gland chromosome III of female Simulium bidentatum. IIIS, short arm; IIIL, long arm; C, centromere; F, flared end; B, blister; $\mathrm{Ca}$, capsule; NO, nucleolar organizer region. Serial numbers and alphabets are as Fig. 1.1 and 2 show range of inversions.

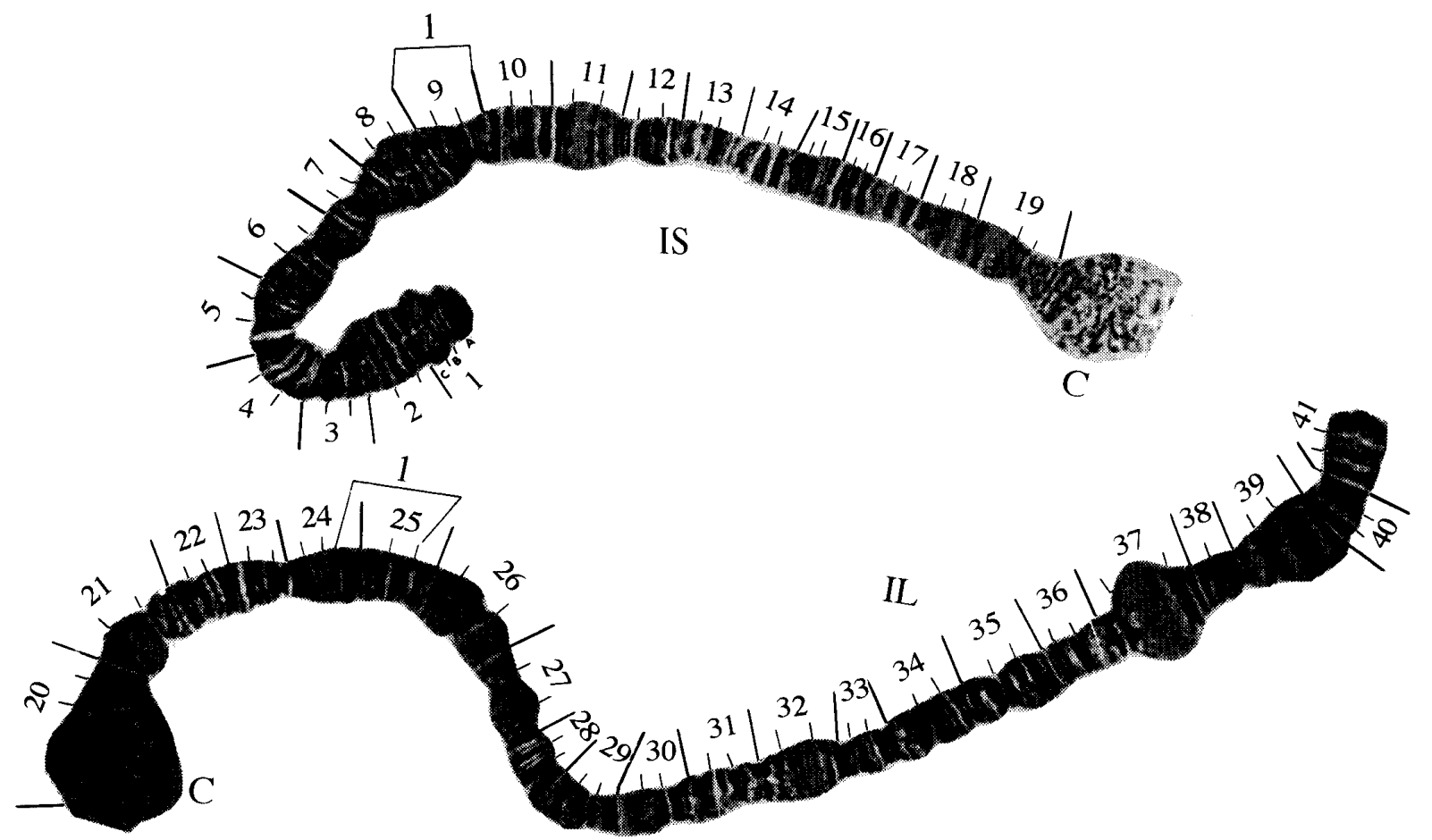

Fig. 4. Larval salivary gland chromosome I of male Simulium aokii. Symbols are as in Fig. 1. 1 shows range of inversion.

both sexes. The frequencies were generally low (7-18\%), except for the Hasama population which showed a relatively high frequency $(37 \%)$. There was another heterozygous inversion, IIIL-2 (85/86-86/ 87) (Figs. 3 and 9e) which, however, occurred in two female larvae.

S. aokii. The standard chromosome maps of this species are shown in Figs. 46 . The centromeric regions of this species were expanded and composed of spongelike, dotted bands. The IS was characterized by three heavy bands in 16 . The IL had a region of fine bands in $20 \mathrm{~B}-22 \mathrm{~A}$, shield-like pattern in 35A, a group of two heavy bands in $36 \mathrm{AB}$ and $39-40$, and a group of fine light bands in 38B. The IIS was flared at the tip. The RB and $\mathrm{db}$ were located in $44 \mathrm{~B}$ and 46 of IIS, respectively and the tr and $\mathrm{PB}$ in 53 and $64 \mathrm{~B}$ of IIL, 


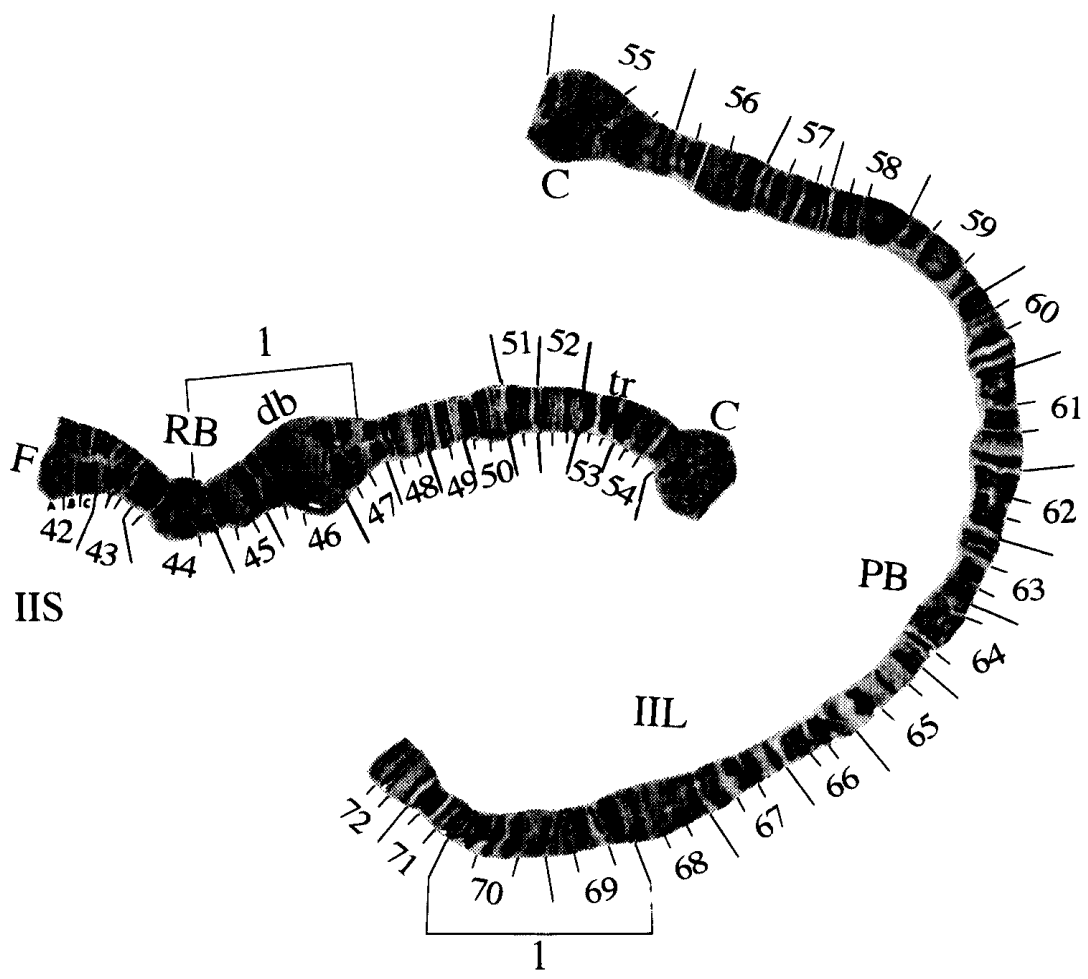

Fig. 5. Larval salivary gland chromosome II of male Simulium aokii. Symbols are as in Figs. 2-3.
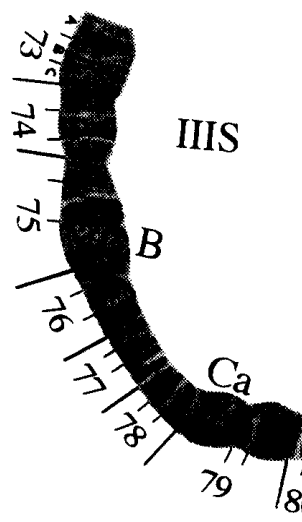

Fig. 6. Larval salivary gland chromosome III of male Simulium aokii. Symbols are as in Fig. 3.

respectively. The locations of $\mathrm{B}$ and $\mathrm{Ca}$ were in $75 \mathrm{BC}$ and $79 \mathrm{~A}$, respectively. The IIIL had the NO in 85 and three heavy band groups in 99 .

In S. aokii, five different inversions (Fig. 9f-i) were found: four in males from the Yufugawa population, i.e., IS-1 (8/9-9/10), IL-1 $(24 \mathrm{C}-25 \mathrm{~B} / \mathrm{C})$, IIS-1 $(44 \mathrm{C}-47 \mathrm{~B} / \mathrm{C})$ and IIL-1 (68/69-70/71), and one in a male from Notsuharu, IIIL-1 (89A-91A/B). Three inversions (IS-1, IL-1 and IIL-1) were also found in the Yufuin population. All these heterozygous inversions occurred at low rate ( $15 \%$ or less).

S. arakawae. The standard chromosome maps of $S$. arakawae are given in Figs. 7 and 8 . The centromeres of all chromosomes were expanded with three distinctive bands. The IS was characterized by a group of two heavy bands in 4 , and three heavy bands in 16 . The IL had a shield-like pattern each in 26 and 33, a 


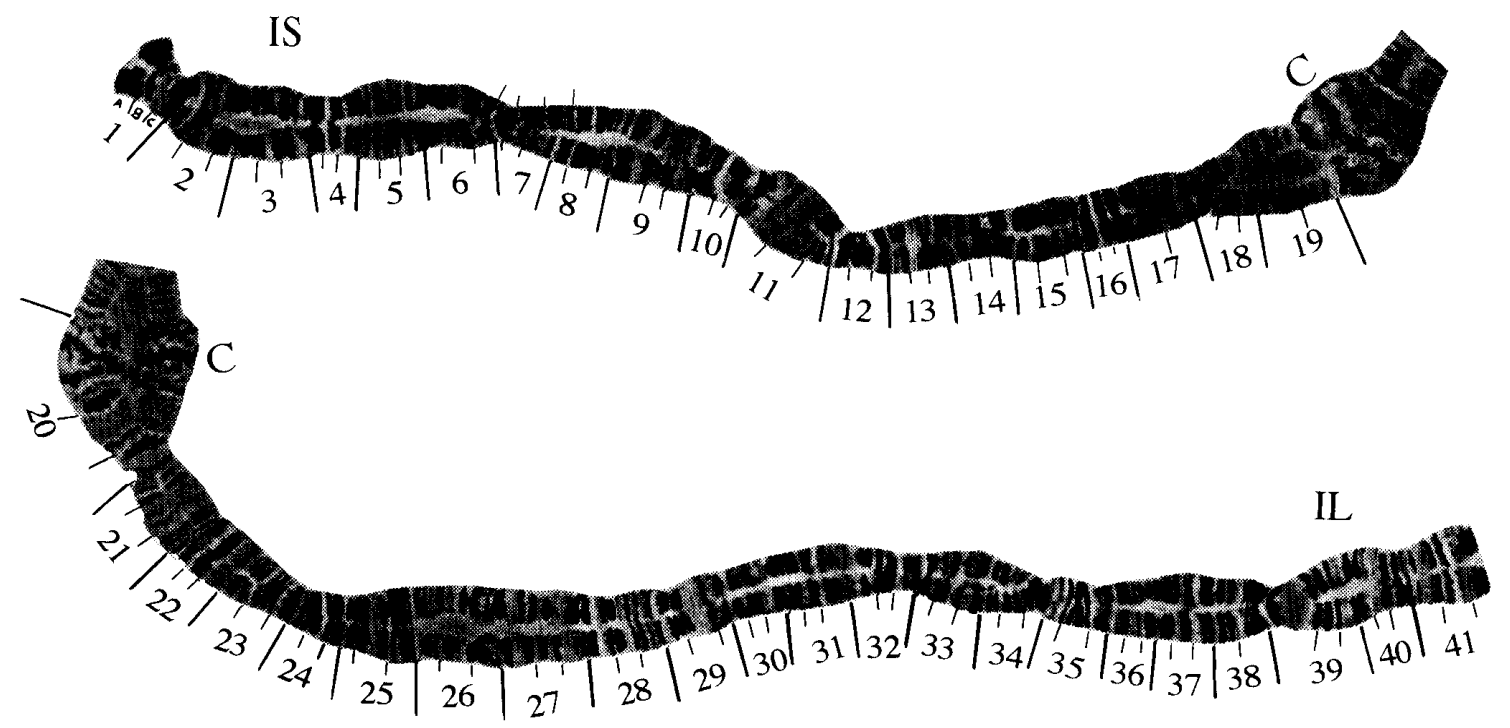

Fig. 7. Larval salivary gland chromosome I of female Simulium arakawae. Symbols are as in Fig. 1.

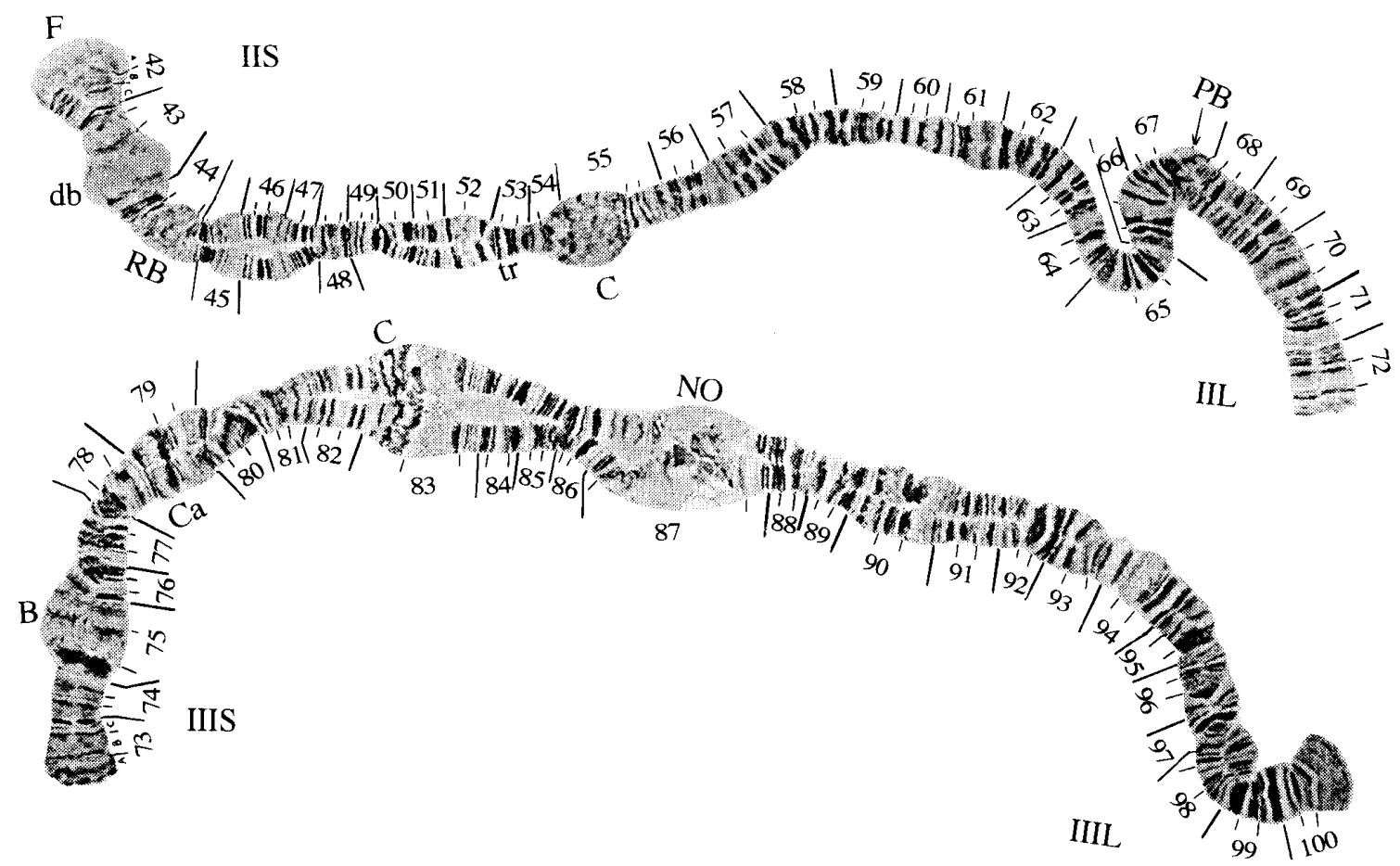

Fig. 8. Larval salivary gland chromosomes II and III of female Simulium arakawae. Symbols are as in Figs. 2-3.

group of fine light bands in $38 \mathrm{~B}$, a group of two heavy bands in 39-40, and fine bands in the distal tip (41C). On the IIS which was characterized by the flared basal tip, the $\mathrm{db}$ and BR were found in 43 and $44 \mathrm{~B}$, respectively and the $\operatorname{tr}$ in 53 ; on the IIL, the PB was in $67 \mathrm{C}$. On the IIIS, the B and Ca were found in 75 and $79 \mathrm{~A}$, respectively. The NO was located at the proximal region of the IIIL (section 87). Three heavy band groups were found in 99 .

No inversion has been found yet, although pairing of chromosomes was very loose.

\section{Discussion}

The three Japanese blackfly species of the subgenus Simulium Latreille s. str. here studied were each assigned in the 

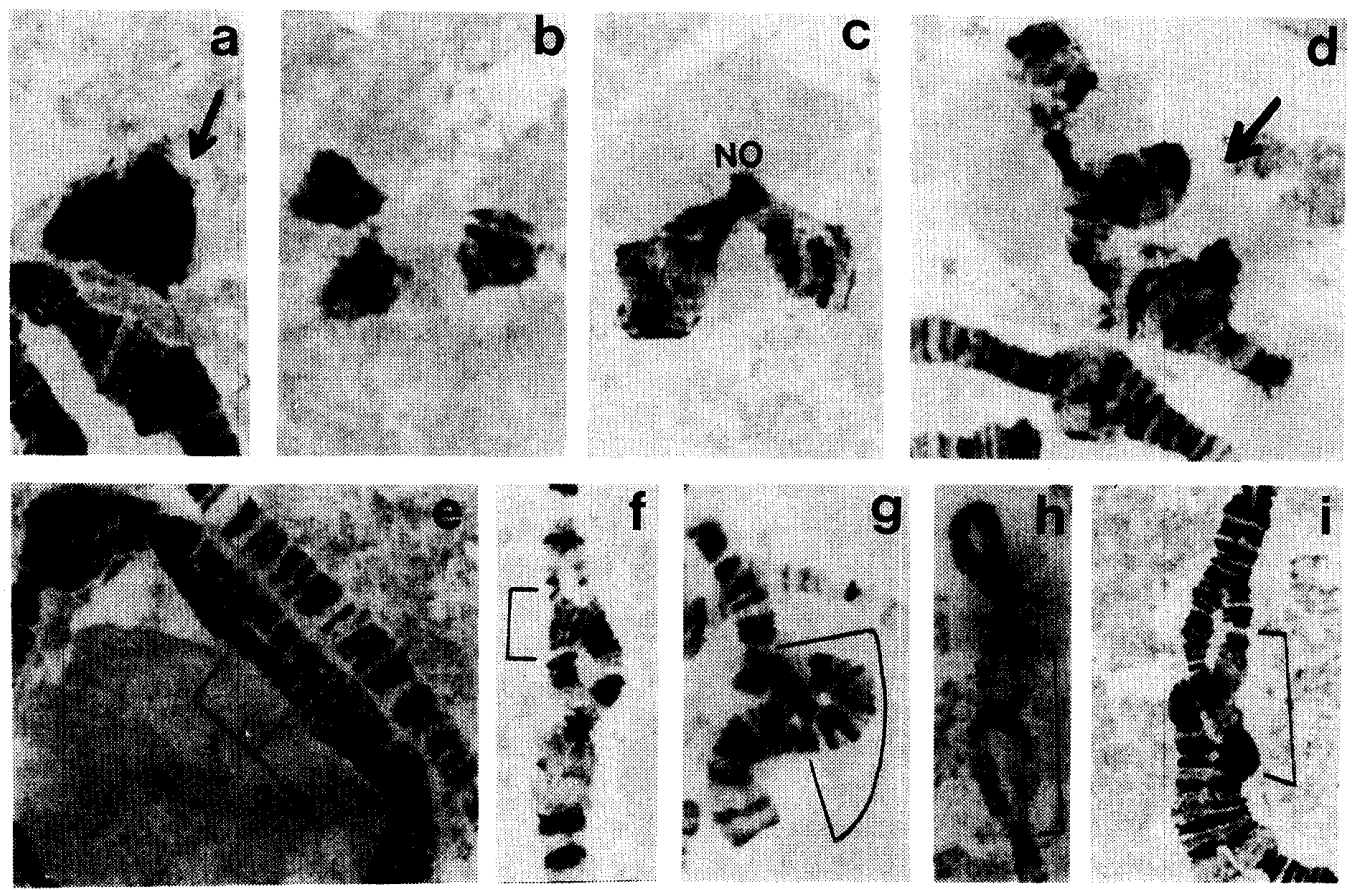

Fig. 9. B-chromosomes and inversions. $\mathrm{a}$ and b, B-chromosomes of female Simulium bidentatum; c and d, B-chromosomes of male Simulium aokii; e, inversions in S. bidentatum (IIIL-1 and IIIL-2); f-i, inversions in S. aokii, f, IS-1; g, IIL-1; h, IIS-1; i, IIIL-1.

different species-groups: i.e., S. bidentatum to the malyschevi-group, $S$. aokii to the variegatum-group and $S$. arakawae to the venustum-group (Crosskey, 1988).

Our results showed that in all three species, there were three pairs of chromosomes $(2 n=6)$, as reported in all other investigated species of the subgenus Simulium s. str. In all three species, certain chromosomal landmarks, such as the RB, $\mathrm{db}, \mathrm{PB}$, and NO were located on the same chromosome arm although their precise locations were different among species. The centromeric regions were prominently expanded but differed in the banding pattern or heterochromatin density by species. The difference of locations of certain landmarks, as well as that of centromeric banding patterns, might be species-group specific. However, more specimens of other related species from various localities are needed to confirm this.

In some populations of $S$. bidentatum and $S$. aokii, B-chromosomes occurred as small metacentrics heavily loaded with heterochromatin and had a nucleolar or- ganizer (Fig. 9a-d), as reported in Cnephia dacotensis and C. ornithophilia (Procunier, 1975, 1982). B-chromosomes have been also reported in several other blackfly species such as, $S$. (Odagmia) ornatum $(=S$. (O.) iwatense) (Okada, 1972), S. venustum (EFG/C) (Rothfels et al., 1978), S. (Nevermannia) morisonoi (Hirai et al., 1984), S. ochraceum (Hirai et al., 1994) and S. (N.) konoi (Hadi et al., unpublished data). The role and effect of B-chromosomes in Simuliidae remain to be studied.

Rothfels (1956) considered that fixed chromosomal rearrangements, sex chromosome differences and the demonstration of a unique array of chromosomal polymorphisms together, indicate existence of reproductively isolated populations. Although polymorphic inversions were found in S. bidentatum and S. aokii, there were neither fixed chromosomal rearrangements nor sex chromosome differences among these populations examined, so providing no evidence of sibling speciation. Similarly, examination of $S$. arakawae has revealed no cytotype differences yet. Future studies may disclose 
whether these species are composed of more than one sibling species, the presence of which is strongly suggested by their wide distribution in Japan and successful adaptation to various types of habitats.

\section{ACKNOWLEDGEMEnT}

We are indebted to Dr. H. Hirai, Primate Research Institute, Kyoto University, for his valuable advice to this work and critical reading of the manuscript.

\section{REFERENCES}

Bedo, D. G. (1977) Cytogenetics and evolution of Simulium ornatipes Skuse (Diptera: Simuliidae). I. Sibling speciation. Chromosoma, 64: 37-65.

Crosskey, R. W. (1988) An annotated checklist of the world blackflies (Diptera: Simuliidae). In: Blackflies: ecology, population management, and annotated world list (ed., Kim K. C. and R. W. Merritt), pp. 425520, The Pennsylvania State University Press, University Park, Penn.

Dunbar, R. W. (1966) Cytotaxonomic studies in blackflies (Diptera: Simuliidae). In: Chromosomos Today Volume One. (ed., Darlington, C. D. and K. R. Lewis), pp. 179-181, Oliver \& Boyd, Edinburgh.

Hadi, U. K., H. Takaoka and C. Aoki (1995) Larval salivary gland chromosomes of the blackfly, Simulium (Gomphostilbia) yaeyamaense (Diptera: Simuliidae) from Ryukyu Islands, Japan. Jpn. J. Sanit. Zool., 46: 235-239.

Hirai, H., W. S. Procunier, J. O. Ochoa and K. Uemoto (1994) A cytogenetic analysis of the Simulium ochraceum species complex (Diptera: Simuliidae) in Central America. Genome, 37: 36-53.

Hirai, H., H. Suzuki and T. Okazawa (1984) Cytotaxonomy of blackflies from Tokara Island. Jpn. J. Sanit. Zool., 35: 187 (in Japanese).

Levan, A., K. Fredga and A. A. Sandberg (1964) Nomenclature for centromeric position on chromosomes. Hereditas, 52: 201-220.

Ogata, K. (1955) Observation of the animal preference of Japanese blackfly. Appl. Zool., 20: 83-89 (in Japanese).

Okada, K. (1972) B-chromosomes in the blackfly, Simulium (Odagmia) ornatum (Meigen), collected in Nagano Prefecture, Japan. La Kromosomo, 87: 2766-2770 (in Japanese with English summary).
Okada, K. (1974) On the morphological features of the salivary gland chromosomes of blackfly, Simulium (Eusimulium) mie Ogata et Sasa. Juntendo Daigaku Bunrigaku Kiyo, 17: 20-27 (in Japanese with English summary).

Procunier, W. S. (1975) B-chromosomes of Cnephia dacotensis and C. ornithophilia (Diptera: Simuliidae). Can. J. Zool., 53: 1638-1647.

Procunier, W. S. (1982) The interdependence of Bchromosomes, nucleolar expression and larval development in the blackfly species: Cnephia dacotensis and C. ornithophilia (Diptera: Simuliidae). Can. J. Zool., 60: 2879-2896.

Rothfels, K. H. (1956) Blackflies: sibling, sex, and species grouping. J. Hered., 47: 113-122.

Rothfels, K. H. (1979) Cytotaxonomy of blackflies (Simuliidae). Ann. Rev. Entomol., 24: 507-539.

Rothfels, K. H., R. Faraday and A. Kaneps (1978) A cytological description of sibling species of Simulium venustum and $S$. verucundum with standard maps for the subgenus Simulium Davies (Diptera). Can. J. Zool., 56: 1110-1128.

Takaoka, H. (1977) Studies on black flies of the Nansei Islands, Japan (Simuliidae; Diptera). III. On six species of the subgenus Simulium Latreille. Jpn. J. Sanit. Zool., 28: 193-217.

Takaoka, H. (1994) Natural vectors of three bovine Onchocerca species (Nematoda: Onchocercidae) and seasonal transmission by three blackfly species (Diptera: Simuliidae) in central Kyushu, Japan. $J$. Med. Ent., 31: 404-416.

Takaoka, H., C. Aoki and H. Hayakawa (1992) Natural infection of blackflies with larvae of zoonotic Onchocerca spp. in northeast Japan. Jpn. J. Trop. Med. Hyg., 20: 1-9.

\section{摘要 \\ 日本産ブュ 3 種の幼虫唾液腺染色体}

Simulium bidentatum (キアシッメトゲブュ) S. aokii (アオキツメトゲブュ) およびS. arakawae (ヒメアシマ ダラブュ）の幼虫の唾液腺染色体を観察し，標準染色体 図を作成した， 3 種とも染色体の基本数は $n=3$ で, Balbiani ring, double bubble, Parabalbiani ring や仁形成 部などの主な特徴は 3 種のブュで同一染色体の同じ腕 に見られたが，正確な位置は種ごとに違いが認められ た. 中心体は 3 種とも顕著であったが, へテロクロマチ ンの成す縞模様は種別に異なっていた，逆位はキアシッ メトゲブユとアオキツメトゲブユに低率で見いだされ た．Ｂ染色体もこの 2 種に見出だされた．性を決定する 染色体の同定は出来なかった。 